\title{
Siriusly Concerned: Animal Non-Belongingness in a Dichotomized Environment
}

\section{Siriusmente preocupados: la no pertenencia animal en un entorno dicotomizado}

\author{
Jesús Fernández-Caro ${ }^{1}$
}

Como citar este artículo: Fernández-Caro, J. (2021). Siriusly Concerned: Animal Non-Belongingness in a Dichotomized Environment, Pangeas. Revista Interdisciplinar de Ecocrítica (núm. 3) 69-78. https:// doi.org/10.14198/PANGEAS.18848

\begin{abstract}
This article approaches Sirius (1944), by Olaf Stapledon, from a perspective that brings together literary animal studies and ecocriticism. The eponymous main character of this science fiction novel is a genetically-modified dog who struggles between the human and the animal realms, being unable to belong to either urban or natural spaces. I argue this work of fiction carries out an exercise of blurring boundaries, thus proposing alternatives for harmful binaries such as humananimal, city-nature, or divine-mundane. Each of these binaries is explored in three trips of the many this character experiences throughout the novel. This allows the main character to reflect on his peculiar, unique species as the singularity he is. Sirius claims it is only empathy that can help in such a task; both human and nonhuman animals are then able to rejoice in biological, cultural, and spiritual differences. Sirius's trips are analyzed in order to look closely at (1) the dog's reflections on humankind while being in London, (2) his becoming a wolf, dog, and human at the same time in the woods, and (3) music as the ideal tool to articulate one's spirituality based on a reconnection with an almost lost biodiversity.
\end{abstract}

Key words: literary animal studies; ecocriticism; science fiction; Stapledon; belonging; postmodern.

\section{Resumen}

El presente artículo realiza un acercamiento a Sirius (1944), de Olaf Stapledon, desde una perspectiva que unifica estudios de animales en literatura y ecocrítica. El personaje protagonista de esta novela de ciencia ficción es un perro modificado genéticamente que se encuentra en una incómoda posición entre el mundo humano y animal, siendo así incapaz de pertenecer ni a espacios urbanos ni naturales. Se sostiene que esta obra de ficción desarrolla un ejercicio de ruptura de fronteras entre los binarios humano-animal, ciudad-naturaleza y divino-mundano, ofreciendo a cambio alternativas menos conflictivas. Cada uno de estos binarios se explora a lo largo de tres viajes que permiten al personaje protagonista reflexionar acerca de su especie tan peculiar. Sirius declara que solo la empatía puede ayudar para tal cometido; los animales, sean humanos o no, podrían entonces entender diferencias biológicas, culturales y espirituales como rasgos positivos de una experiencia común. Este trabajo analiza los tres viajes de Sirius para observar (1) las reflexiones del perro acerca del ser humano en su estancia en Londres, (2) los devenires animales que hacen que Sirius sea lobo, perro y ser humano a la vez en un entorno no urbano y (3) la música como la herramienta idónea para que un individuo articule su espiritualidad, basada en una reconexión con una biodiversidad casi perdida.

Palabras clave: estudios de animales; posmodernismo; ecocrítica; ciencia ficción; Stapledon.

1. Jesús Fernández-Caro. Universidad de Cádiz. fernandez.caro@uca.es https://orcid.org/0000-0001-6494-1473 


\section{INTRODUCTION}

Olaf Stapledon's Sirius (1944) presents a German shepherd, or Alsatian, as the protagonist of a science fiction novel whose abilities exceed the borders of the animal and penetrate the human. His awkward speech - though sufficient for communication -, the acquired control of his forepaws, and his academic disposition make him stand out as a superb specimen, the result of a scientist's genetic experiment. Taking belonging as a key theme, the author recreates Mary Shelley's Creature in the shape of a dog. Thus, trapped between the human and the animal worlds, Sirius explores the frontiers of these realms through three trips of very different nature. This article proposes an approach to Stapledon's text combining two critical methodologies: animal studies and ecocriticism.

The former has rapidly gained international attention as nonhuman animals start to be considered a figure of Otherness, apart from its evident social impact in the questions of our time (Richter, 2011). Specifically, literary animal studies seek a (re)evaluation of the animal figure, paying close attention to the different modes of representation from allegoric animals to metaphoric to postmodernist. Ecocriticism facilitates a path on which animals can be linked to their environment, as well as it paves the way for considerations on human impact. How humans interact with other animals, then, becomes a primary object of study in order to understand specific literary animal representations. It is only logical to presume a more complete picture when combining both methodologies, as the emphasis is put on how the constructs of human, animal, and nature are reproduced, questioned or challenged.

First, it is necessary to bear in mind the role of science fiction in ecocriticism. Being an incredibly imaginative genre, authors ascribed to science fiction are allowed to explore beyond almost any kind of limitation, whether social, political, religious or sexual. The way the world is transformed into a futuristic or alternative reality speaks for the environmental issues that affect the author's times. Stapledon is often regarded as a visionary whose fiction is best understood from a modernist perspective. This way, being "aware of the disastrous effect that the exclusion of animals has had on our planet," his fiction turns to "an ecological sensibility that understands the creative complexity of our existence" (Ittner, 2005: 99-100). As one of the possible interpretations, Sirius can be viewed as a text that reacts to animal abuse and obliteration, particularly affected by the horrors of World War I. This view is shared on a more general scale by Bullock, who claims our sudden animal awareness "may have come about only because we can imagine a world without animals, now that our powers of destruction have grown so monstrously" (2002: 118).

Stapledon achieves a magnificent modernist mise en abyme through which readers get lost in locating a narrator. The book takes the form of a biography written by a secondary character who listens to Sirius's recollections of his life, warning the reader about several communication problems as well as deliberate editing of the dog's words. This complicates the study of the literary text, as reliability throughout the narration is categorically rejected. Whatever morals readers get, it is delivered by a one-of-a-kind process of collection of information that is amalgamated, at times contradictory, and purposely distorted. Such an effect not only leaves readers in a position of disbelief regarding what is accounted but also displays an interesting array of layers of subjectivity, making it apparent from the very beginning that no real truths can ever be found in this fake biography.

This literary trope, though common in modernist literature, is salient in science fiction in the forties. Along the same lines, intertextuality lies at the core of the novel's plot structure. Thus, Frankenstein resonates through the entirety of the text allowing Stapledon's work to be read as a reimagining of Shelley's work from the perspective of an animal character, as well as it allows for continuing the conversation started in the early nineteenth century about the philosophical nature and political rights of nonhumans. Of course, these are strategies that need to be deployed when the main character is a dog. Leaving the restraints of realism behind, Stapledon turns to more experimental devices that would let him explore spiritual ecology from an unconventional character.

Choosing a genetically modified dog as the main character is no trifle, not to mention letting him express his understanding of existence through music since "Stapledon abandons any hope of finding a suitable means 
of verbal communication due to the liability of misinterpretation" (Boyarkina 2018: 15) . While some critics regard the novel as a "poignant story of the struggle of a spirit to achieve community, and the failure of this struggle" (Rabkin 1982: 239), I argue the novel works on three separate levels based on three trips Sirius makes. The present article is structured following such trips, namely: London, the forest, and the beyond.

In the first trip, Sirius finds himself in a completely new environment, having lived in the countryside during all his childhood and great part of youth. Excited about the prospect of the advancement of learning, the dog embraces the scientific discourse that is promulgated by the University his master and creator works for. As he becomes more involved in the academic world, his interest in the scientific method decreases, noticing there are questions that make logical thought collapse. He ceases to search for truth in science only.

His second trip takes place in a more scattered fashion since getting lost in the forest is presented as an escape mechanism when the dog finds himself unable to handle human selfishness and pride. Whenever Sirius steps into the wilderness, Stapledon plays with his animal side, blending dog and wolf. It is quite impressive how the character truly finds personal growth while resorting to activities commonly understood as primitive. No involution takes place in the novel, although the balance of human and dog genes sure is played out, as Sirius finds it difficult to give up his nonhuman animal instincts after hunting, fighting, and roaming free.

Throughout the entirety of the literary text, and parallel to the two previous trips, Sirius embarks on a spiritual trip that finally proves to be the one that actually brings valuable knowledge and experience. Putting an emphasis on the fact that he does not need to isolate his dual nature in either city or natural environment, the dog is allowed to reflect on all of his life events from the point of view of an uplift animal. That is, because of his advanced nature, Sirius is both superior to all other characters in the novel and an imperfect blend of flawed species. Being a scientific achievement, Sirius takes musical performance as the best way to explore Stapledon's philosophical concerns. This is "the power of the best sci-fi, [as] it straddles the divide between the speculations of science, philosophy, and art" (Blake, et al., 2012: 4). Befriending a priest, Sirius challenges religious dogma and embraces a kind of spirituality that is as much ecological as philosophical. In his numerous ruminations on the nature of species, the role of human beings on Earth, and human-animal interaction, his thoughts are always sparked by observation of the environment, which is more often than not affected by humans.

\section{CITIZEN DOG}

After living in his hometown in Wales for more than he could handle, Sirius is finally granted the opportunity to travel to Cambridge. His interests lie in city life, the university, and Homo sapiens behavior. Fascinated by the immense libraries he visits, it does not take him long to accept being received at the university as both a scholar and a subject to experiment on. While he expects to obtain a certain degree of self-achievement with his academic progress, he soon realizes urban routine wears him out. His very instincts wither so much that he ends up finding how "a note of sadism crept into his love making" (Stapledon, 1944: 102). At times, he even hurts the only bitch who is brought into his room. This dehumanization process in Sirius's character is a wonderful paradox, for he has never been human.

The dog's reaction to the metropolis is twofold. If Sirius is taken as a human character lacking a human body, this trip becomes a critique of the disconnection from the natural world citizens suffer, being Cambridge a poisonous place for any living being. On the other hand, if Sirius is understood as a dog that has been granted a higher plane of existence, then human animals are depicted as completely detached from the rest of the species since only they can bear living in such a place. Indeed, Sirius is not a typical literary animal character but this does not stop the literary figure to carry out, as expected, a moral at the end of the trip: animals do not belong in cities.

Several issues arise at this point. In the first place, it must be taken into consideration that Sirius can be viewed as a metaphor and parable in this trip. And, however revolutionary the whole novel might be, Stapledon faces the main problem of metaphor, that of "arriving at the same old 
conclusions, namely that animals are only literary as human subjects" (McHugh, 2006: 4). As an inheritor of the Aesopian tradition, the author takes Sirius's journey with the simplest approach to the animal. Secondly, and as Vint (2008) reminds us, "in science fiction, the animal can be given a voice to address and to look back at the human." This is exactly what Sirius's voice does. His voice turns into a sharp, poignant speech that criticizes humans in any possible way. Readers face speciesism back to front, being the human the one that is condemned. Sirius does not hesitate to remind his creator that "in making me you made something ${ }^{1}$ that sees man from clean outside man, and can tell him what he looks like" (Stapledon, 1944: 91). Taking this as the main goal of Sirius's trip to Cambridge, it is convenient to examine how humans are connected with the environment.

So, the city is depicted as an anti-natural place, the physical realization of human power which is based on an anthropocentric view of the environment. Such a place becomes suddenly disconnected from any nonhuman life form. The urban setting is highly mechanized, inhabited by beings that are only in contact with members of their species. Urban humans ignore biodiversity and this causes a lessening or even a perversion of their vital functions. The few actual descriptions of the city that can be found in the novel remain too plain, in contrast to long paragraphs devoted to a romantic portrayal of natural settings. In other words, the city cleaves species: those who are human, and those who are not.

Shaw takes Cambridge descriptions as a way of showing how "homo sapiens ha[s] floundered into a mechanized situation too difficult to handle" (2010: 153). Certainly, technological abuse is a central theme of the novel, constantly anthropomorphized by a genetically modified dog that challenges human notions of the natural order. When it comes to Sirius's reflections on this topic, he considers it is all about selfishness. Forgetting about other species is humans' main flaw: "What

\footnotetext{
1. Note the use of something instead of someone. Sirius's identity is never fixed throughout the novel. There are times he is objectified, while in many chapters he is described as an individual, a superb specimen that cannot be differentiated from any other human being but from its physical appearance.
}

a species to rule a planet! And so obtuse about everything that wasn't human! So incapable of realizing imaginatively any other kind of spirit than the human!" (Stapledon, 1944: 107, original emphasis). His desperation is expressed in multiple cries full of exclamation marks, reinforcing Sirius's helplessness for half belonging to a species that carries out self-centered actions in a suppressed environment that is never questioned. He ends up concluding that "they must be insensitive really; drunk with self, and insensitive to all else" (Stapledon, 1944: 106).

Although the city of Cambridge is never portrayed as a concrete forest, it does function as a suppressive environment for Sirius's instincts. He comes to understand that the more academic success he gets, the less alive he feels. There is a clear separation between being a scholar and actually learning something. Sirius realizes the kind of knowledge he once sought is futile and lacks profoundness, particularly about his interests in the spirit (i.e. philosophical concerns). While he struggles to make up his mind about what he really needs, he spends entire days lost in his thoughts and feeling "completely disorientated and futile, spiritually enslaved to the will of man" (Stapledon, 1944, 103). This internal battle is a permanent trope throughout the novel, as it brings about Sirius's characterization as either a dog that is too human or a human in the shape of a dog. This is, humanity and bestiality are explored in terms of the main character's decisions about his personal, academic, and spiritual/philosophical drives. His instability is partly due to his undeniable distrust of human beings. As a dog, he needs to feel he belongs to a pack, as well as it is essential to identify a leader to follow. The leader's actions are always followed by the pack but they are also an object of evaluation. Whenever the pack considers the leader is not deserving of their role, another will replace them.

This article claims that what Sirius does here is express his discomfort with his leader, human beings, about the way they relate to other life forms in an artificial space they call city. How humans may have become Sirius's leader is simple. First, because he was created by a human being; and secondly because "size is significant in nature," for "if an animal is large enough to eat you, you tend to give it more credence" (Aloi, 2012: 55). Sirius's size, which is frequently 
mentioned, serves a clear purpose: to establish a relationship of domination. His having a larger head than other dogs clearly refers to a superior intelligence, while his body remains its normal size, emphasizing his weakness in the city.

The fact that Sirius is turned into a determined critic of the lifestyle of urban humans is actually what triggers the moral mentioned earlier. Not only is the author "trying to raise the sensibility of society to the problems related to the progress of eugenics" (Boyarkina, 2016: 9) but he is also reminding us humans of our history with dogs and how harmful selective breeding has been for them: "As he drifted along the streets, he felt stifled by the surrounding herd of the grotesque supersimians who had conquered the Earth, molded the canine species as they trimmed their hedges, and produced his unique self" (Stapledon, 1944: 104). It is not accidental that Sirius regards humans as a "surrounding herd of grotesque super-simians" since he is, after all, a German shepherd. And of course, it is most interesting how anthropocentrism is displaced by reminding readers about the evolution of our species. Nonetheless, what is most interesting in this quotation is the emphasis that is placed on how Sirius victimizes dogs and so points at humans as culprits - based on breeding. Just as humans intervene in dogs' genes, "producing his unique self," they are likely to continue altering natural arrangements that should not be meddled with.

Therefore, Sirius's relationship with humans experiences a radical change the moment he understands human nature. Not only does he lack a leader but can no longer find one worthy. His metaphysical worries urge him to find a spiritual leader that takes existence as more than a mere being-in-the-world. Agamben takes on Heidegger's concept of Weltarmut to explain animals' beingin-the-world. This means animals are usually regarded as "poor in world" insofar as they cannot alter their ontology. As he puts it, "for the animal, beings are open but not accessible; that is to say, they are open in an inaccessibility and an opacity - that is, in some way, in a nonrelation" (2004: 55). Once this theoretical framework is applied to Stapledon's text, it can be concluded that urban humans are depicted as more closed beings. Humans are not valid for such a task since their city has shown Sirius how unaware and uncaring they are about other life forms.

\section{WILD DEMI WOLF}

Sirius's rejection of city life finds its opposite in innumerable trips to deep forests in his country of origin, Wales. Free from human restraints, this uplift dog can enjoy the pleasures of wildlife letting his instincts go wild. This does not only mean he is able to interact with a more natural environment but also engage with his nonhuman side. He carries out multiple hunts that make him repudiate humanity: "His deeper nature, his unconscious nature, had found expression. He had discovered something far more satisfying than human sophistication" (Stapledon, 1944: 38). In order to analyze Sirius's becoming a demiwolf ${ }^{2}$, I am taking two terms from two critics whose work is closely concerned with animal representation. The first is "sensory ecology" (Smith, 2005), which alludes to a literary recreation of the animal ontology by making full use of the senses. On the other hand, McGuirk (2008) signals some animal characters in science fiction as "heroesof-becoming" as they break a species barrier by following other animals' behavior or by possessing other animals' characteristics.

Sight is, undoubtedly, the most important of the human senses as it is the one we Homines sapientes rely on in order to survive and achieve progress. When it comes to literature, everything depends on it; reading is mainly a monosensorial experience that, in the case of animal narratives, intends to evoke plurisensorial responses. Namely, literature involving animal ontologies tends to aim at a certain sensory ecology that allows readers to cross the bridge between species in an exercise of empathy so as to commune with the animal other. Such an experience often causes a bittersweet aftertaste for it involves accepting certain behaviors as completely natural and necessary, in contrast to what they would initially consider improper, censurable or disgusting. Take, for example, Sirius's joy when ramming his fangs into another dog's neck:

The warm blood seeped into his mouth and threatened to choke him, but he hung on, coughing

\footnotetext{
2. The use of this term intends to insist on the vacuity of speciesist terminology when a character is made to belong to three species at the same time.
} 
for breath. The saltness and odour of Diawl Du's blood, he afterwards said, turned him mad. Some pent up energy and fury in him was released for the first time. At the height of the struggle the thought flashed upon him, "This is real life, this is what I am for, not all that human twaddle." He gripped and tugged and worried, while Diawl Du's struggles became weaker, and the horrified human beings did their best to loosen his grip. (Stapledon, 1944: 37)

I consider this excerpt a perfect example of an attempt at a sensory ecology focused on taste. What is achieved here is an antagonism between "human twaddle" and an intense sensorial experience that is disapproved by humans. From an ecocritical perspective, this fragment unfolds certain matters worth commenting. First of all, there is a particular curiosity on the reader's side regarding the thrill of the hunt. As humans do not take down other animals using brute force nor feed on raw meat, such an experience can only be imagined. Most humans would no doubt label an episode like this as "horrible, just animal" (Stapledon, 1944: 39). What is significant is how we human beings categorize this practice, for the human-animal divide is reinforced and thus the environment is perceived as something brutal, merciless, completely alien. A renewed reading of such passages would bring to light how humans feel attracted to these stories precisely because they are not allowed to experience them. At the same time, this could suppose a less anthropocentric view of the environment, as the constructs city and nature would give way to broader terms that should target an inclusive purpose. Namely, human beings are just one more species that must learn to - or be reminded of - coexist with others.

Secondly, the disgust that arises when exposed to such a reading comes with an echo of the fear Homo sapiens once experienced about being eaten alive. This is what Bulliet (2007) calls "carnivore monsters" in literary representation; horribly terrifying animal characters threaten the safety of our homes by showing how much they enjoy killing in a natural surrounding. Again, this points at the blurring of species barriers as it generates a sudden feeling of becomingprey in the reader. It is precisely the subversion from predator to prey that is most interesting in this ecocritic reading. Humans who are used to considering themselves the dominant species are thrown back to a position of weakness all of a sudden, being reminded how vulnerable they are whenever they are stripped of their constructed urban spaces. As Derrida reminds us: "Mortality resides there, as the most radical means of thinking the finitude that we share with animals, the mortality that belongs to the very finitude of life, to the experience of compassion, to the possibility of this nonpower" (2002: 396).

In Stapledon's novel, multiple images are deployed by means of which home environments are contrasted to natural - or free from human contact - surroundings, and it is the dog himself who reflects "on the hills alone in the winter dawn" about the fact that "the warm fireside and friendly talk at Garth were just a rare accident," before a scenery of snowy valleys pecked with "miserable dark sheep pawing for food" (1944: 70). When facing desolation and inclement weather - a passage that reminds us of Victor Frankenstein's encounter with the Creature - the whole human world is reduced to a tiny happening in time and space, depicting human comforts as an eventuality which, however convenient, is bound to crumble. Such a realization makes Sirius detached from other life forms, inhabiting a position of non-belonging in an environment that is dichotomized, split into an either-city-or-nature cleavage he does not associate with. While it is true this condition is actively sought by the author to enable the character's reflections on humans and other animals, it is also evident there is a crucial questioning of species barrier in relation with human intervention in the environment. In other words, Sirius can be said to be, in the universe of the novel, the highest scientific - or at least biological - achievement of the time. His tragic life, however, contrasts the presumed advancement of science with the actual right human beings have to intervene in genetic modification and creation of species. It is much more than the clichéd trope of playing God, for Sirius's account is not deemed as pure misanthropy but rather an overcoming of human power and influence.

Lastly, it is time to bounce back to the concept of heroes-of-becoming explained at the beginning of this section. Sirius's body is strictly canine, featuring small traces of otherness, such as a bigger head or a fixed gaze. His non-belonging to a closed species allows him to belong to several of them. That is, the 
role that bodies play in Stapledon's novel is critical as animal studies cannot overlook Deleuze and Guattari's work (1987). Sirius's becoming affects, at least, dogs, humans, and wolves. His body does not only favor such shifts but also is described differently depending on the animal he becomes. More interesting still is the reason why he becomes a demi wolf: not having a human body makes him feel so frustrated that his primary instincts get intensified. This is highly linkable to ecocriticism for bodies cannot limit experiences of becoming. If humans are branded as arrogant because of their lack of empathy, bodies are not the ones to blame since a becoming occurs through naturalsocial practices.

Does this becoming take place in a way that all life forms involved in it are considered as equally important? Stapledon's Sirius seems to mirror his novel Odd John, whose main character is an uplift human. Both Sirius and Odd John appear as fictions of individuals who are ahead of their race, which causes a great harm in the fictional ecology they are inserted into. As Swanson observes, "Òhumans would do better to attempt to elevate the lower orders of species than to refine themselves out of spirituality and human existence" (1982: 291), thus maintaining a clear dividing line between low and high rank species. Even if hybridization is applied on Haraway's terms, understanding "biological organisms" as "mosaics, chimeras[,] biotic systems, communications devices like others" (1985: 313), Sirius resists being pinned down to the usual categorization of literary characters as tools.

Perhaps it would be necessary to take into account other ways of reading literature that do not study the logics of becoming but explore them in a more experiential fashion. Starting from the premises that this modernist literary text refuses hegemonic scientific discourse and that there is an intention of an alternative perception of human-animal ecosystems, it would be fair to ask criticism to express new awareness of the environment and the lives that characterize it.

Nonetheless, one tends to get the feeling that the deleuzoguattarian idea of becoming gets too abstract, too disconnected from actual empathetic achievements. Some critics do not hesitate about signaling this philosophy as one that "retains and reproduces all the characters that Western tradition attributed to the Animal, and thus remains within this tradition" (Salzani, 2017: 104). What is sought here is a more powerful approach that responds to the incredibly sensorial reading experience heroes-of-becoming offer. I humbly suggest recognizing certain literary texts as modernist animal narratives. This would allow new, fresher perspectives, away from traditional studies of the animal in contrast with the human - if such a thing is possible. Taking Sirius as an example, a special emphasis should be placed on the influence of romanticism and the sublime and on how they affect interspecies communication. Weil agrees that "to focus on the sublime is to recognize the dangerous inadequacy of our language for communicating experiences outside our consciousness" (2010: 11).

No matter how much is said about animal representation, all conclusions are derived by a human critic. This obvious assertion affects animal studies and ecocriticism since, "despite confidence in the interventionary powers of art, some ecocritics complain that we are still guilty [...] of containing the animal in the intellectual zoo of our conceptions" (Rainwater, 2005: 275). This feature, widely referred to as the paradox of animal representation, creates a critical impasse since it is not possible to say anything definitive about the roles of animals in literature while attempting to do so is unavoidable.

For the moment, it must be concluded that literary animal representations remain unpaired, for literary criticism does not have the right tools just yet. Probably, postmodernist animal narratives require an approach that balances feeling and reason. As Costello articulates in Coetzee, "seen from the outside, from a being who is alien to it, reason is simply a vast tautology" (1999: 25).

\section{SPIRITUAL MUSICIAN}

One main common feature of animal studies and ecocriticism is their unconcealed rejection of anthropocentrism. The fact that both critical methodologies turn to biocentrism (which, in contrast to the former, takes all kinds of life as the center of logos) makes them suitable to form a strong alliance when facing a literary work. Ultimately, it is all about decentering human beings as the pristine figure of knowledge. In the case of Sirius, music is regarded as a bridge towards 
what the dog calls the spirit; the singer embarks on a spiritual journey that is about to change him forever by making him able to connect with it all.

This trip differs from the other two in that it does not take place as an isolated experience, framed in a subplot or a separate chapter. On the contrary, Sirius's spiritual journey is developed all throughout the novel, which is significant by itself. As the main character is affected by his immediate surroundings, so his music is altered every time, mirroring Sirius's soul, essence, spirit, or any term readers see fit. His first musical compositions arise from the extreme aversion he feels towards human music, which sounds too shrill and out of tune. His superior sense of hearing gets combined with his human musical knowledge, and so he strays from human settlements to try his voice out. This image sure reminds readers of wolves howling to the moon, which is slightly modified in Stapledon since Sirius rather sings to the stars. Sirius's name alludes both to serious and Sirius, two homophones alluding to a somber and thoughtful character, and the brightest star in the sky, respectively.

His singing evolves and eventually catches the attention of one of his human acquaintances, a human priest who lets him sing at the mass. After his nonhuman music fills the church, humans are left with so strange an aftertaste that they do not even know what to make out of what they have just listened to. The priest tries to explain with words what Sirius means in that composition, what his purpose is, as well as how the audience is supposed to react. However, his efforts in trying to communicate such an experience through human language remain "a sorry attempt to superimpose an analytical frame over a profoundly emotional and spiritual experience" (Nollman, 2010: 268). Thus, Stapledon makes use of music to show how inadequate and imperfect human language is. Spirituality cannot be experienced utilizing only reason, and so music is the most appropriate instrument.

AstoSirius'sthoughtsabouthumanspirituality, it is worth mentioning how he criticizes religious buildings as the only places in which humans are thought to aim at a higher plane of existence. In other words, there is a conception of spirituality as a trip that is not bound to anything material. No physical space is needed to exercise one's spirit, Sirius argues, especially when only one species is allowed in such spaces: "not in this way, [not] for the sake of the mere warmth of togetherness, could one find the essential spirit, identical in himself and in these humans" (Stapledon, 1944: 115-6). He then adds one more feature to what he considers vital for the spiritual quest, that of otherness: "Only in the most articulate, precise self - and other - consciousness was the thing to be found" (Stapledon, 1944: 116).

To take music as the ultimate tool for spirituality is fairly common in animal studies analyses. While Stapledon applies an identity trip through music to a work of fiction, several renowned philosophers also evaluate the connection between music, emotion, and spirituality. Deleuze and Guattari (1987), for instance, consider art as a cultural practice deeply linked to the process of becoming: "Singing or composing, painting, writing have no other aim: to unleash those becomings. Especially music" (272). On the other hand, though less explicit, it is significant to bring Agamben's (2004) comments on Uexküll's work (1934). When examining animal ontologies, the former describes Umwelt as "an infinite variety of perceptual worlds that [...] are linked together as if in a gigantic musical score" (40).

Sirius's spiritual trip makes him perceive the environment from a perspective that could very well be attached to Darwinian ideas of evolutionism. Species seem to belong to a neverending, progressive transformation from senseless creatures to superior beings. Human beings are then signaled as the key species for their special ability of spirituality. As Swanson (1982) admirably claims, Stapledon depicts species as beings that are "programmed for self-destruction in its [sic] need to transmute itself into a higher or more versatile species [...] Animals must become human, humans must become gods, gods must transcend their divinity" (285). Sirius certainly blurs the divides between the animal, the human, and the divine. His death is, in fact, described as something that is bound to happen as humanity is not prepared for such a spirit.

The fact that Sirius is granted the power of speech is meaningful as it is, after all, the only medium through which his spirituality can be expressed in a literary work. Surprisingly, he states it is all about rejoicing in features of otherness. Note how the author makes use of an ambiguous referent so as to allude both to love and the spirit as the subjects of the sentence. The wordplay is kept in order to maintain its original effect. "The more 
different, the more lovely the loving" (Stapledon, 1944: 50). Love is signaled as one of the ways to reach the highest climax of the spirit, making it very clear that "it feeds on differences" (Stapledon, 1944: 139). This justifies his rejection of anything involving only one species, as individuals are thought to get benefit from sharing their (meta) physical experience with other living beings. Humans are not denied such a spiritual exercise but are described as beings who voluntarily refuse any kind of interaction with any nonhuman animal. Thus, human beings not only isolate themselves in constructed spaces they call cities but also inside constructed spheres based on speciesism.

In all, Sirius's spiritual trip entails development from an objectified animal (i.e. shepherd dogs in the novel) to a being who has access to higher spiritual experiences. Stapledon performs a most prophetic telling of an animal that is shifted "from anthropocentric instrumentality to zoocentric empathy" (Franklin, 1999: 175) since readers are subject to a catharsis that allows them to feel pity for Sirius's death, and especially how it is brought about. In a Frankensteinian fashion, the dog is killed by humans that do not accept such an outrageous Other. What is particularly remarkable is the fact that it is the dog himself who creates the path for readers to experience empathy by expressing his spiritual concerns.

\section{CONCLUSIONS}

Sirius depicts human animals living in physical and spiritual isolation due to an undeniable lack of biodiversity. City and nature become constructed spaces that get reinforced through Sirius's experiences and reflections. Neither sphere seems convenient enough for the dog since he comes to understand the vacuity that characterizes them. As Sirius is trapped between Canis familiaris and Homo sapiens, so he is deprived of a defined location in which he can fully exercise his nature. His non-belongingness results in a search for a metaphysical space where his spirit can develop thanks to musical performance. Stapledon's novel epitomizes a species that has been selectively bred in such a savage way that Sirius transcends the very barriers of species.

This article shows the dog's reaction to the three different environments, joining animal studies and ecocriticism, proving they are "two paradigms [that] should be considered simultaneously distinct and complementary" (Armstrong \& Simmons, 2007: 1). It becomes crucial to look closely at science fiction texts with a clear nonhuman animal presence in order to bring together animal studies and ecocriticism more often so as to understand to what extent this approach is fruitful. To theorize about animals, whether human or not, is to discuss ecology inasmuch as the whole set of animals reshape the environment. Similarly, an analysis of animals in literature should be carried out giving great importance to how natural and urban spaces are dealt with. If it is assumed that setting is a key element in a work of fiction because of its role in characterization, then it is crucial to address environment descriptions as available connections to our surroundings. That is, animal fiction not only questions human-animal but also animal-environment interactions. It is only a matter of time to learn about the myriad of different ways in which our surroundings can be conceived.

For these reasons, this article argues that whenever a narrative is led by an animal voice, ecocriticism should be present as a piece of the methodological ensemble. In Sirius, the binaries human-animal, wild-urban, and mundane-divine are blurred and thus challenged. What is offered, then, is a zoocentric alternative based on empathy in a biodiverse space that favors difference over the self. And, as fixed concepts are confronted, animals can only find a healthy relationship with their immediate surroundings by inhabiting whatever space favors an advancement of the spirit. In the case of Sirius, a genetically-modified dog that simply cannot define himself as purely human or canine, it is his spirituality that eases him and finally puts an end to his search for a place to belong.

\section{WORKS CITED}

AGAMBEN, G. (2004). The Open: Man and Animal. Meridian, crossing aesthetics; Variation: Meridian (Stanford, Calif.). Stanford: Stanford. ALOI, G. (2012). "Beyond the Pain Principle.", in Charlie Blake, Claire Molloy, and Steven Shakespeare (eds.): Beyond Human: From Animality to Transhumanism. London: Continuum, 50-73. 
ARMSTRONG, P., and SIMMONS, L. (2007). "Knowing Animals Bestiary: An Introduction", in Laurence Simmons and Philip Armstrong (eds.): Knowing Animals. Leiden: Brill, 1-24.

DOI: https://doi.org/10.1163/ ej.9789004157736.i-296.7

BLAKE, C., MOLLOY, C., and SHAKESPEARE, S. (2012). Beyond Human: From Animality to Transhumanism. London: Continuum.

BOYARKINA, I. (2016). "Per Aspera Ad Astra. Conflicts and Challenges of Spirit in Sirius by Olaf Stapledon", in Postgraduate English, (33), 1-25.

BOYARKINA, I. (2018). "Utopia in the Histories of the Future by H. G. Wells and W. O. Stapledon", in Foundation (129), 6-19.

BULLIET, R. W. (2007). Hunters, Herders, and Hamburgers: The Past and Future of HumanAnimal Relationships. New York: Columbia.

BULLOCK, M. (2002). "Watching Eyes, Seeing Dreams, Knowing Lives", in Nigel Rothfels (ed.): Representing Animals. Bloomington: Indiana University Press, 98-118.

COETZEE, J. M. (1999). The Lives of Animals. New Jersey: Princeton UP.

DELEUZE, G., and GUATTARI, F. (1987). A Thousand Plateaus: Capitalism and Schizophrenia. Minneapolis: University of Minnesota Press.

DERRIDA, J., and WILLS, D. (2002). "The Animal That Therefore I Am (More to Follow)", in Critical Inquiry, 28 (2).

DOI: https://doi.org/10.1086/449046

FRANKLIN, A. (1999). Animals and Modern Cultures: A Sociology of Human-Animal Relations in Modernity. Wiltshire: SAGE.

HARAWAY, D. (2003). The Companion Species Manifesto: Dogs, People, and Significant Otherness. Prickly Paradigm Press. Chicago: Prickly Paradigm Press.

ITTNER, J. (2005). "Who's Looking? The Animal Gaze in the Fiction of Brigitte Kronauer and Clarice Lispector", in Mary Sanders Pollock, and Catherine Rainwater (eds.) Figuring Animals: Essays on Animal Images in Art, Literature, Philosophy, and Popular Culture. New York: Palgrave, 99-118.

DOI: https://doi.org/10.1007/978-1-137-09411-7 7

McGUIRK, C. (2008). "Science Fiction's Renegade Becomings", in Science Fiction Studies, 35 (105).

McHUGH, S. (2006). "One or Several Literary Animal Studies?", in H-Net, 16/07/2006.
NOLLMAN, J. (2010). "Field Studies: Ethics of Communication Research with Wild Animals", in Marc Bekoff. (ed.), Encyclopedia of Animal Rights and Animal Welfare. Santa Barbara: Greenwood, 265-269.

RABKIN, E. S. (1982). "The Composite Fiction of Olaf Stapledon", in Science Fiction Studies, 9 (3), 238-248.

RAINWATER, C. (2005). "Who May Speak for the Animals? Deep Ecology in Linda Hogan's Power and A. A. Carr's Eye Killers", in Mary Sanders Pollock and Catherine Rainwater (eds.), Figuring Animals: Essays on Animal Images in Art, Literature, Philosophy, and Popular Culture. New York: Palgrave MacMillan, 261-280.

RICHTER, V. (2011). Literature After Darwin. Human Beasts in Western Fiction, 1859-1939.

DOI: https://doi.org/10.1057/9780230300446

SALZANI, C. (2017). "From Post-Human to PostAnimal Posthumanism and the 'Animal Turn'", in Lo Sguardo, 24 (II), 97-109.

SHAW, B. (2010). The animal fable in science fiction and fantasy. Jefferson: McFarland \& Company.

SMITH, J. A. (2005). "Sensory Experience as Consciousness in Literary Representations of Animal Minds", in Mary Sanders Pollock and Catherine Rainwater (eds.), Figuring Animals: Essays on Animal Images in Art, Literature, Philosophy, and Popular Culture. New York: Palgrave, 231-246.

DOI: https://doi.org/10.1007/978-1-137-09411714

STAPLEDON, O. (1944). Sirius: A Fantasy of Love and Discord. London: Orion.

SWANSON, R. A. (1982). The Spiritual Factor in "Odd John" and "Sirius", in Science Fiction Studies, 9 (3), 284-293.

UEXKÜLL, J. (1934). "A Stroll Through the Worlds of Animals and Men: A Picture Book of Invisible Worlds", in Claire H. Schiller (ed.), Instinctive Behavior: The Development of a Modern Concept. New York: International Universities Press, 4-80.

VINT, S. (2008). "The Animals in That Country: Science Fiction and Animal Studies", in Science Fiction Studies, 35 (105).

WEIL, K. (2010). "A Report on the Animal Turn", in Differences: A Journal of Feminist Cultural Studies, 21 (2).

DOI: https://doi.org/10.1215/10407391-2010-001 